\title{
INTERROGATING THE CONCEPT 'OPENNESS’ IN OPEN DISTANCE LEARNING (ODL)
}

\author{
Cosmas Maphosa ${ }^{1 \mathrm{i}}$, \\ Sithulisiwe Bhebhe ${ }^{2}$ \\ ${ }^{1}$ Institute of Distance Education, \\ University of Eswatini, \\ Eswatini \\ ${ }^{2}$ Faculty of Education, \\ University of Eswatini, \\ Eswatini
}

\begin{abstract}
:
Scholars in Open Distance Learning (ODL) often refer to distance education as 'open'. The concept 'openness' on open and distance learning is very fluid and often misunderstood. It is the purpose of this desktop survey to review relevant literature and make interrogation of the concept 'openness'. We advance questions such as; How open is open and distance learning. In what aspects is ODL open and to what extent is the openness. We discuss openness concerning targeted potential students and entry requirements in ODL institutions, the openness of teaching, and learning approaches as well as openness concerning communication, the flexibility of curricula, and assessment. We conclude by answering whether or not ODL institutions are open as well as suggesting measures and ways of enhancing openness in ODL institutions.
\end{abstract}

Keywords: open learning, distance education, curriculum flexibility, learning, distance learners, open education

\section{Introduction}

Open and distance learning (ODL) entails the opening access to education and training provision, delivering learners from the limitations of time and place, and offering flexible learning opportunities to individuals and groups of learners (UNESCO, 2002: 7). The foregoing view is premised on the assumption of the problem of access to education and training. The traditional classroom-based face-to-face instruction has limitations in terms of accommodating all potential students in institutions of higher learning. Many potential

i Correspondence: email maphosacos@yahoo.com 
students in sub-Saharan Africa are out of school because they cannot be accommodated in conventional institutions. ODL comes in handy to address such a challenge.

Providing educational opportunities to people in different countries is important as a means of empowerment. Bordoloi (2018: 25) asserts that:

"Providing opportunities for education to the people also means that a country can protect them against all sorts of discriminations, provide them with the required opportunities, and make them empowered in every aspect of life in the true sense."

The empowering value of education makes it mandatory for governments of different countries in the world to seek for ways to provide education, especially higher education, to all the citizens. The utilisation of high-quality flexible modes of delivery becomes significant instead of face-to-face classroom systems. Conventional higher education systems often fail to meet the demand of the population in terms of higher education needs and hence the need for other higher education avenues by reaching out to the unreached (Srivastava, Kurup \& Nembiakkim, 2007). To this end, ODL serves to provide knowledge and skills to those who did not have access to learning by providing "instruction to the learners at their doorsteps through various media and technology" (UNESCO, 2002 cited in Bordoloi (2018: 30).

\section{Openness concerning targeted potential students and entry requirements}

An important characteristic of openness in ODL is the removal of barriers to learning. ODL should target all potential students without restrictions of age, marital, or employment status, among others (Bates, 2005). For a long time open and distance learning has been to offer educational opportunities to students who, for one reason or another, could not have access to the traditional and conventional face-to-face educational system (McAndrew, 2010; Littlejohn \& Pegler, 2014). Openness, in this regard, referred to enhanced access. Dalsgaard and Thestrup (2015) assert that there could be a political motive behind opening access to education to all. Emphasis on education for all by the United Nation agencies such as the UNESCO resulted in initiatives in "initiatives that ensure that ODL provides the right to education for all irrespective of age, ethnicity, gender, and social status" (UNESCO, 2002; 2015 cited in Selvaras, 2019: 2). Openness in ODL as a focus on the removal of hindrances of access to learning cannot be overemphasised (UNISA, 2008). The convenience and flexibility of ODL have enabled millions of people to access higher education and this would have been an impossibility without ODL (Sharma, Kawachi, \& Bozkurt, 2019).

To understand the nature of students attracted to ODL, the view by Nigam and Joshi (2007) is worth considering, when they state that ODL systems "have become a feasible and viable alternative to those who were denied education due to one reason or the other" (Nigam \& Joshi, 2007) cited in Kuruppuarachchi \& Karunanayake, 2017: 42). Such students could be some already in different forms of employment with a willingness to still pursue high education qualifications. ODL is, therefore, open to working students, mostly adults, who 
have to reconcile between their work engagements and study commitments. These students would not be able to study full-time because of work commitments and ODL becomes an ideal and viable alternative. The barrier of not being able to study because of work commitments is thus removed.

ODL institutions often have flexible entry requirements as an element of openness, with the view to enhance access to higher education for many. The Open University of Malaysia (OUM), for example, spearheads the Malaysian government's initiative of widening access to higher education in what is known as the democratization of education. The OUM has a flexible entry system for many people who do not meet the basic entry requirements to further their studies at a higher level. Such applicants who are admitted through flexible entry route, use "their prior learning and work experience for admission into the University" (Ahmad, Nik \& Kamariah, 2014). On the issue of open entry route at OUM, Latif, Fadzil and Yick (2009: 118) state that:

"The concept of open entry, derived from the philosophy of recognition of prior learning $(R P L)$, acknowledges learning gained through formal, non-formal, and informal means and allows alternative access to higher education with less restrictive entry requirements compared to conventional universities."

The fact that potential students may use prior learning and work experience as entry requirements if they do not meet the minimum entry requirements proves the openness of entry qualifications to ODL programmes. According to Jain (2013) cited Rupande and Nyenya (2014: 24) the difference between ODL and the conventional education system is that "ODL provides adequate flexibility in terms of "entry" and "exit" points to a learner". The flexibility of entry and exit points for the learners' points to the element of openness. The ODL system thus is a user-friendly system (Singh \& Das, 2019). Trindade, Carmo, and Bidarra (2000), however, contend that openness in terms of entry requirements does not imply that there are no basic requirements for access. For one to successfully study for a university qualification, a certain level of numeracy and literacy is required.

\section{Openness concerning affordability}

Another element of ODL is in its affordability to learners. Rupande and Nyenya (2014) aver that ODL is both highly inclusive and affordable. Similarly, on the issue of affordability, Ojo, Ogidan, and Olakulehin (2006: 5).

"It is often a cheaper means of attending school for the student since some people may not be able to leave their places of work to go to school full time. For employers, ODL offers the possibility of organizing in-service training for their staff without necessarily releasing them for long periods of productive time." 
The above view shows that ODDL is an affordable way to study for students and employers. Students can pursue their studies without disturbances or inconveniences of having to move away from families and workplaces. In terms of work commitments, students learn and earn at the same time, which is of mutual benefit for staff and employers. Workers engage in improving their knowledge and skills without any disadvantage to the employer.

In underscoring the affordability of ODL as an element of openness, Moore and Tait (2002 p. 22) aver that the purpose of ODL is to provide learners with a chance to undergo education and training irrespective of geographical, socio-economic or other constraints. ODL is not elitist and learners from humble backgrounds should be able to afford it.

\section{Openness concerning teaching and learning methods/approaches}

Open distance learning is an approach that entails an educational quasi-separation of the learner and the instructor in time and space (Keegan, 1996), meaning that learning can take place anytime and anywhere and in any form as a way of enhancing openness (Sharma, Kawachi \& Bozkurt, 2019). Naidu (2017:1) also states that "A key attraction of distance education has always been the flexibility it affords in terms of the time, place and pace of learning and teaching. At the heart of distance education is freedom from uniform schedules and location to be able to learn or teach." Trindade, Carmo, Bidarra, (2000) reveal that there are a single-mode and dual-mode of instruction in ODL institutions. In the single-mode systems, learners are expected to work mainly on their own off-campus, while in a dualmode, learners have an opportunity to work with tutors, visiting study centres or do block, winter, or summer intensive courses, depending on their institute.

Educational planners in developed and developing countries have seen the institution of a single-mode open and distance learning universities as a means of addressing national education needs (Khakhar, 2001). Trindade, Carmo, and Bidarra (2000) postulate that a mixed-mode approach has been the most successful experience of ODL in many institutions in China where Central Radio and Television University is one of the largest ODL systems in the world, which delivers course content through satellite transmissions to classrooms. In this mode of delivery, learners work by themselves and interact with their instructors in the central system through wide-band terrestrial cable communication. Thus, teaching and learning approaches for ODL need to match the nature of the learning approach and portray some openness.

Blended learning is one approach to education that utilizes both online educational materials and opportunities for interaction online with traditional placebased classroom methods (Innovative Learning solutions, 2020). In ODL correspondence between instructor and students or between classmates are through e-mail, message boards, or virtual learning systems (Ofole, 2018). Mariluz, Covadonga, Gorka, and Alicia (2006) reveal that ODL rests on Information and Communication Technologies (ICT) available in society. The blended learning approach has been the most widely used and 
effective way in most developing countries and this approach has demonstrated some degree of adequacy for self-learning students.

Khakhar (2001) postulates that Open distance learning institutes are mandated to make all efforts to establish a fully integrated open distance learning system with appropriate approaches for developing course materials and providing learner support and instruction to enhances openness in the programme. Afunde (2016) reveals that in some ODL institutions, during registration, students are issued with study materials and assigned to study groups that get aid from a qualified mentor within the region where the students reside. The learners then get an opportunity on scheduled times to meet with the mentor who facilitates discussions guided by a course outline to ensure consistency across the programme. The mentor's presence during sessions is to give learners opportunities for discussions, collaboration, and exchange of ideas and resources (Killian, 2012).

Mobile technology is one of the tools that may be used in ODL institutions to enhance communication. The results of a study done at the Namibian College of Open Learning (NAMCOL), by Afunde (2016) revealed that all the learners enrolled for ODL submitted their mobile numbers, meaning that they had access to mobile technology, but only $20 \%$ had contact to the Internet. The NAMCOL report (2016) reveals that the college provided print-based study materials in the form of study guides and tutorial letters to the enrolled ODL learners, as an approach to ensure that those who did not have access to the internet at least get printed material. Similarly, Maboe (2017) points out that in ODL learners should have sufficient resources that are appropriate to back up their learning. Afunde (2016) further reveals that the college used mobile technology in the form of bulk text messaging mainly for administrative purposes and for communicating information to ODL learners. Mariluz, Covadonga, Gorka, and Alicia (2006) point out that there is the use of information and communication technologies (ICTs) as an approach for teaching and learning in ODL institutions. ODL institutions need to assess the learners' ability to succeed in online learning through the use of ICTs (Tomei, 2008).

\section{Openness concerning technology integration}

Open and distance learning is characterised by separation of the instructor and the learner, the learner is separated from group learning. Communication in ODL is mainly mediated by technology (Kuruppuarachchi \& Karunanayake, 2017). On the same note, Mariluz, Covadonga, Gorka, and Alicia (2006) also reveal that ODL teaching and learning lean on technological research and development activity happening globally. Thus, integrating technology into open and distance learning is very vital for the success of online learning (Sharma, Kawachi \& Bozkurt, 2019). There are various technological tools used for delivering ODL, these are radio, television, computers, mobile devices, and satellite use has prominently been highlighted in research literature globally (Turow, 2016). 
Selvaras (2019) points out that technology is a vital factor in the modern world even in education and especially in ODL where the learner is physically separated from the instructor. The presence of technology in ODL has benefited most of the activities learners are expected to do. The use of technology in ODL has advanced both learning and teaching. Thus, integrating technology to the instructor (Khumalo, 2018).

It is vital to integrate technology into all ODL institutions. Maboe (2017) conducted a study in South Africa and the results of the study revealed $84.9 \%$ of students own computers, and $100 \%$ own cellular phones, but only $3.8 \%$ participated in the online discussion forum. In this study, some students indicated that they were technologically challenged, while, some instructors interacted minimally online. It was also a finding that the institution was not giving the instructors enough platform to acquire the necessary skills to utilise these technologies. Thus, institutions are mandated to ensure that ODL learners have access to the internet and that instructors are trained to utilize the different platforms used to communicate with learners to increase the degree of openness in ODL.

Integrating technology in ODL facilitates blended learning. Selvaras (2019) conducted a study in Siri Lanka and found that most of the ODL learners had access to technology through mobile phones and were conversant with blended learning. Even though they preferred distance learning, they did not prefer learning entirely in isolation. Learners chose to use social media and mobile application modes as part of blended learning. The instructors also acknowledged the access and use of blended learning. Learners in ODL are open to blended learning where social media is used.

The ODL institutions also must ensure that learners are motivated to use technology in their learning. Maboe (2017) in a study conducted in a university in South Africa revealed that ODL learners were encouraged by the university to interact online through the discussion forum and also use e-mails to facilitate teaching and learning. On the same note, Balaji (2010) indicated that the use of an online discussion forum is currently a common tool and an effective way of engaging students in discussions done outside the classroom. Thus, technology use in ODL enhances openness to communication amongst learners and instructors.

\section{Openness concerning communication}

Communication is vital in ODL as it assists in reducing the transactional distance between instructors and learners (Berge, 2013). Moore (1991) explains transactional distance as being influenced by course structure and dialogue and communication between course instructors and students should be enhanced to reduce distance education learners' feelings of isolation. Timeous and meaningful communication between learners and course tutors enhanced levels of learner engagement. Learnerlearner and instructor-learner interaction are deemed to be significant in creating fruitful DL environments (Moore \& Anderson, 2007). Moore and Kearsley (1996: 200) posit that the separation between the course instructors and students in distance learning "leads to communication gaps, psychological space of potential misunderstandings between the behaviours of instructors and those of the students". Once the transactional distance is reduced, this 
results in what Shin (2003) refers to as the "transactional presence" which is the learners' level of connectedness to teachers, peer students, and the institution. Effective communication is important in addressing the transactional distance, for effective teaching and learning to take place.

Open and distance learning is also flexible regarding communication between and among learners. In a related study, Fahy (2003) found that ODL students supported each other in academic and social matters. Technology integration in ODL enhances communication between and among students. Anderson and Dron (2011: 81) observes that ODL needs to "be technologically mediated to span the geographic and often temporal distance between learners, teachers, and institutions..." Effective communication bridges the gap between students and the institutions and between students. In underscoring the importance of digital technologies, Dalsgaard and Thestrup (2015: 84) state that such technologies are "mobile, ubiquitous, and provide opportunities for exchange, inspiration, and production of content across time and space". The use of technologies to enhance communication is underpinned by the Connectivist pedagogy in ODL (Siemens, 2005; Downes, 2007). As a pedagogy, connectivism places a strong emphasis on knowledge construction and application (Anderson \& Dron, 2011).

Flexible communication in ODL should also be enhanced through relevant pedagogy hinged on social constructivism. McKerlich and Anderson (2007) state that social interaction is pivotal in ODL teaching and learning and hence opportunities should be provided for interaction between students as well as between students and instructors. Similarly, Tait (2000) observes that learning interaction and interactivity are major factors affecting the success of students in ODL.

\section{Openness concerning flexible curricula}

Higher education institutions in general and ODL institutions in particular deal with students of great diversity in terms of age, social and cultural backgrounds, personal and professional experiences as well as technological literacy (Severiens, Wolff, \& Van Herpen, 2014). This issue of diversity calls for institutions to adapt curricula to meet the different needs and capabilities of students (Rao \& Meo, 2016). Naidu (2017) states that ODL;

"... is by nature the most flexible form of learning and teaching. This flexibility may go far beyond the freedom from time, place, and pace to include freedom of choice about issues and topics one might study as well as the type of assessment activities that one might choose to take in return for what kind of credit and at what cost."

Meier (2007) reveals that flexible curricula in ODL entail litheness in the mode of learning. The initial modes of learning in ODL were the multi-media learning mode and the tele-learning mode then the current one that has brought in more flexibility and openness in ODL is the online learning and web-technologies mode. Musingafi, 
Mapuranga, Chiwanza, and Zebron (2015) point out that, institutions in developing countries are still using a mixed-mode in ODL. CQ University Australia (2020) states that,

"Students studying in mixed mode will participate in a combination of online learning activities in addition to site-specific learning activities, which may include residential schools, co-op placements, and/or work-integrated learning as a compulsory requirement of a unit."

In a mixed ODL mode, there is face-to-face as well as online and web-technologies (Latchem, 2018). The mixed-mode in the ODL is open for those learners who want to mix both face-to-face and online learning and the instructors need to be trained for this type of mode (Carmo, \& Franco, 2019).

\section{Openness in ODL concerning the assessment}

In ODL assessment is one vital part of the learning process that should be well-planned. Gil-Jaurena (2013:1) states, "Learning assessment is established as a key process in education." Chaudhary and Dey (2013) also reveal that there are several assessment strategies used in ODL and the current shift is now from content-based testing to performance-based assessment. Assessment is no longer used for grading and certification, rather it has related to learning and students' skills development. A variety of assessment techniques are now utilised to assess learning and learners. Openness in ODL is also judged by new and diverse forms of assessment, which assist to provide better assessment decisions on students learning and the learning process, without focusing on being judgemental on students.

Mishra (2012) points out that ODL learners are in most cases assessed through printed texts, audios, and videos. The assessments of this kind happen after submitting a set of assignments for continuous assessment and the last part of the assessment is normally the pen and paper examination which takes place under the normal set examination conditions of an institute for openness. Schophuizen (2020) reveals that in ODL teaching and learning are using open educational resources and the testing is through open assessments where certificates are awarded to show for the acquired competences. Gil-Jaurena (2013:1) states that;

"Learning assessment in open and distance education is facing new challenges and scenarios, due to current or renewed conceptual and political frames -such as the-Credit Transfer and Accumulation System (ECTS) - and to the increasing number of developments in the technological and pedagogical fields -such as automatic assessment tools or peer grading in massive open online courses."

Ngara, Ngwarai, and Mhute (2012) conducted a study at the Zimbabwe Open University (ZOU) where ODL is practiced. The study focused on the opportunities provided as well as the challenges to quality assurance associated with the assessment 
methods such as assignments, examinations, practicum/portfolios, and research projects. The results of the study revealed that there was a challenge in the originality of learners' work such as assignments and projects and the learners' practical work was hardly monitored in the current ODL setup. The study by Ngara, Ngwarai, and Mhute (2012) also revealed that learners have their assignments and projects done by relatives and slip away with it in the current set-up resulting in an incomplete ZOU graduate.

\section{Ways of enhancing openness in ODL}

Several ways could be instituted in ODL to enhance openness. As much as ODL is inclined to ICT, institutes must ensure that all instructors have gone through Computer Based Training (CBT) to be able to guarantee the success of blended learning approach and increase the degree of openness in ODL (Mariluz, Covadonga, Gorka \& Alicia, 2006).

Trindade, Carmo, and Bidarra (2000) point out that instituting a mixed-mode of instruction, whereby the ODL and the conventional streams are concurrently applied, in the same institute, for the same programme may bring openness. The mixed-mode approach will allow that part of the student workload, previously spent in the classroom and taught by an instructor, to be substituted by self-learning activities.

To enhance openness in ODL, there is a need to have excellent technical quality and internet quality in e-learning and currently, internet quality has improved in most countries due to the launch of 3G and 4G internets (Aftab, Sarwar, Khan \& Kiran, 2019). Liaw, Huang, and Chen, (2007) list several aspects that need to be considered in developing the e-learning framework for openness in ODL, as technology quality, environmental satisfaction, learning activities, and learners' qualities.

Instituting quality assurance management is one measure of enhancing the success and achievement of openness in ODL. Mahlangu (2017:2) explains that,

"Quality assurance is that part of a quality management system assuring that quality requirements will be met. It includes those entire planned or systematic activities essential to provide enough evidence that the service will meet the required needs."

Open and Distance learning institutes need to have quality assurance tools in place and these should be constructed and handled by staff who are engaged and involved in the construction of these tools as they can easily relate or implement them as desired (Mahlangu, 2017).

\section{Conclusions}

The study concludes that there are many approaches to ODL that institutes have employed. These are single-mode, dual-mode, and mixed-mode. The study also concludes that ODL is inclined to ICT. The study also concludes that quality assurance management is a measure of openness and success in ODL. 


\section{Recommendations}

The study recommends that to enhance a higher level of openness in institutes of ODL learners need to have access to the internet and instructors need to be trained on how to use the ICT tools as well as using different platforms for communication. The study also recommends that quality assurance be put to place especially on the assessment of ODL learners.

\section{Conflict of interest}

The authors declare that there is no conflict of interest.

\section{About the authors}

Cosmas Maphosa is a Professor and Director in the Institute of Distance Education at the University of Eswatini in Eswatini.

Sithulisiwe Bhebhe is a Senior Lecturer in the Primary Education Department, Faculty of Education at the University of Eswatini in Eswatini.

\section{References}

Aftab, J. Sarwar, H. Khan, A. H. \& Kiran, A. (2019). Critical Factors Which Impact on Students' Satisfaction. A Study of e-learning Institutes of Pakistan. Asian Journal of Distance Education, 14 (2), 32-46.

Afunde, N. L. (2016). The Potential of Open and Distance Learning in Enhancing the Provision of Psychosocial Support: A Case Study at NAMCOL Paper ID: 00559. http://oasis.col.org/bitstream/handle/11599/2618/PDF?sequence=4\&isAllowed=y (Accessed 11 April 2020).

Ahmad I. A, Nik A. N. Y. \& Kamariah M. N. (2014). A Comparative Study on Persistency and Performance of Flexible and Normal Entry Learners, Seminar Kebangsaan Pembelajaran Sepanjang Hayat

Anderson, T. \& Dron, J. (2011). Three Generations of Distance Education Pedagogy, International Review of Research in Open and Distance Learning, 12 (3), 80 - 97

Balaji, M. S. (2010). Student interactivity in online discussion forum: Empirical research from a "media richness theory" perspective. Journal of Interactive Online Learning, 9(1), 1- 22.

Bates, A. W. (2005). Technology, e-Learning and Distance Education London: Routledge

Berge, Z. L. (2013). Barriers to Communication in Distance Education. Turkish Online Journal of Distance Education-TOJDE, 14 (1) Article 31.

Bordoloi, T. (2018). Transforming and empowering higher education through Open and Distance Learning in India. Asian Association of Open Universities Journal, 13 (1), 2436. 
Carmo, R. D. S. \& Franco, A. P. (2019). From face-to-face teaching to online teaching: the learning of university teachers in distance education. Educação em Revista. 35 (1), 112.

Chaudhary, S. V. S. \& Dey, N. (2013). Assessment in Open and Distance Learning System (ODL): A Challenge. Open Praxis, 5 (3), 207-216.

CQ University Australia (2020). Mixed Mode. https://www.cqu.edu.au/aboutus/structure/governance/glossary/items/mixed-mode (Accessed 26 April 2020).

Dalsgaard, C. \& Thestrup, K. (2015). Dimensions of Openness: Beyond the Course as an Open Format in Online Education. International Review of Research in Open and Distributed Learning, 16 (6), 78 - 96.

Downes, S. (2007, June). An introduction to connective knowledge. Paper presented at the International Conference on Media, knowledge \& education - exploring new spaces, relations, and dynamics in digital media ecologies. Retrieved from http://www.downes.ca/post/33034.

Ekstrand, B. (2013). Prerequisites for persistence in distance education. http://www.westga.edu/ distance/ojdla/winter164/ekstrand164.html (Accessed 12 April 2020).

Fahy, P.J. (2003). Indicators of support in online interaction. International Review of Research in Open and Distance Learning, 4(1), 1-16. Retrieved from http://www.irrodl.org/index.php/irrodl/article/viewArticle/129.

Gil-Jaurena, I. (2013). Challenges, lessons, and achievements in the practice of distance and e-learning. https://openpraxis.org/index.php/OpenPraxis/article/view/82/51 (accessed 27 April 2020).

Innovative learning solutions, (2020). An Introduction to Blended Learning. https://www.cae.net/blended-learning-introduction/ (Accessed 14 April 2020).

Jain, S. (2013). Enabling continued adult-learning through open and distance learning (Unpublished paper).

Katz, Y. J. (2002). Attitudes are affecting college students' preferences for distance learning. Journal of Computer Assisted Learning, 18, 2-9.

Keegan, D. (Ed.) (1996). Foundations of distance education (3rd ed.). London: Routledge.

Khakhar, D. (2001). A framework for open distance learning - organization and management, Retrieved from https://portlandpress.com/DocumentLibrary/Umbrella/Wenner\%20Gren/Vol\%20 79/vu ch3.pdf.

Khumalo, (2018). Improving Student Success Rate in Open Distance Learning settings through the principle of constructive alignment. https://www.intechopen.com/books/trends-in-e-learning/improving-studentsuccess-rate-in-open-distance-learning-settings-through-the-principle-ofconstruct (Accessed 14 April 2020).

Killian, B. (2012). NAMCOL assessment manual. Windhoek: NAMCOL.

Kuruppuarachchi K. A. J. M. \& Karunanayake, K. O. L. C. (2017). Student characteristics and knowledge on ODL concepts at first registration: A case study from OUSL. 
Asian Association of Open Universities Journal, 12 (1), 41-51 DOI 10.1108/AAOUJ-112016-0004.

Latif, L. A., Fadzil, M. \& Yick, L. K. S. (2009). Persistence and Performance: Does Prior Learning Really Matter? ICI9 - International Conference on Information; Kuala Lumpur, 12 - 13 August 2009.

Latchem, C. (2018). Open and Distance Non-formal Education in Developing Countries. https://books.google.com/books?id=dtBJDwAAQBAJ\&pg=PA11\&lpg=PA11\&dq (Accessed 26 April 2020).

Liaw, S. S., Huang, H. M., \& Chen, G. D. (2007). Surveying instructor and learner attitude towards e-learning. Computers Education, 49(4), 1066-1080.

Littlejohn, A. \& Pegler, C. (2014). Reusing Resources: Open for Learning. Journal of Interactive Media in Education, 1(2).DOI: http://dx.doi.org/10.5334/2014-02.

Maboe, K. A. (2017). Use of online interactive tools in an open distance learning context: Health studies students' perspective. Health South Africa Gesondheid, 2 (2), 221-227

Mahlangu, V. P. (2017). Professional Development of Adult Learners through Open and Distance Learning http://dx.doi.org/10.5772/intechopen.68818 (Accessed 14 April 2020).

Mariluz, C. Covadonga, R. Gorka, L. \& Alicia, O. (2006). Open and Distance Learning Methodologies in Higher Education Spanish National Distance University (UNED-Spain). EADTU's Annual Conference. https://files.eric.ed.gov/fulltext/ED494776.pdf.

McAndrew, P. (2010). Defining openness: updating the concept of" open" for a connected world. Journal of Interactive Media in Education, 2, Article 10.

McKerlich, R., \& Anderson, T. (2007). Community of inquiry and learning in immersive environments 11(4). Journal of Asynchronous Learning Networks 11(4). Retrieved from http://www.sloan-c.org/publications/jaln/v11n4/index.asp.

Meier, E. (2007). Education is a right not a favour. Commonwealth Education Partnerships.https://books.google.com/books?id=ID5XqeV4q10C\&pg=PT97\&lpg= PT97\&dq. (Accessed 26 April 2020).

Mishra, S. (2012). Openness in Education: Some Reflections on MOOCs, OERs, and ODL. Keynote Presentation. International Council for Open and Distance Education (ICDE). Standing Conference of Presidents (SCOP). http://oasis.col.org/bitstream/handle/11599/1038/2012 (Accessed 26 April 2020).

Moore, M. (1991). Distance education theory. The American Journal of Distance Education, $5(3), 1-8$.

Moore, M. G. \& Anderson, W.G. (2007). Handbook of Distance Education. $2^{\text {nd }}$ ed. New Jersey: Lawrence Erlbaum.

Moore, M. G. \& Kearsley, G. (1996). Distance education: a systems view of online learning Belmont, CA: Wadsworth Cengage Learning.

Musingafi, M. C. C. Mapuranga, B. Chiwanza, K. \& Zebron, S. (2015). Challenges for Open and Distance learning (ODL) Students: Experiences from Students of the Zimbabwe Open University. Journal of Education and Practice, 6 (18), 59-67. 
Naidu, S. (2017). Openness and flexibility are the norms, but what are the challenges? http://repository.usp.ac.fj/10851/ (Accessed 27 April 2020).

NAMCOL. (2016). Annual Report. Windhoek: NAMCOL.

Ngara, R., Ngwarai R., and Mhute, I. (2012). Assessment in ODL: Practices, Opportunities, and Challenges. International J. Soc. Sci. E Education, 3 (1), 166-177.

Nigam, A. \& Joshi, V. (2007). Science education through open and distance learning at higher education level. Turkish Online Journal of Distance Education, 8 (4), 20-33.

Ofole, N. M. (2018). Curbing attrition rate in Open and Distance Education in Nigeria: ecounseling as a panacea. Unpublished Ph.D. Thesis, University of Ibadan, Nigeria.

Ojo, O. D., Ogidan, R. \& Olakulehin F. K. (2006). Cost-Effectiveness of Open and Distance Learning in Nigeria: Responses from Focus Group Discussions. Online Journal of Distance Learning Administration, 9 (2), 2 - 11.

Ozkan, S. \& Koseler, R. (2009). Multi-dimensional students' evaluation of e-learning systems in the higher education context: An empirical investigation. Computers $\mathcal{E}$ Education, 53(4), 1285-1296.

Rao, K., \& Meo, G. (2016). Using universal design for learning to design standards-based lessons. SAGE Open, 6(4), 1-12. https://doi.org/10.1177/2158244016680688

Rupande, G. \& Nyenya T. (2014). Accessibility and Affordability of ODL in Zimbabwe: A Reality or a Myth? International Journal of Humanities Social Sciences and Education, $1(4), 21-29$.

Selvaras, J. (2019). Technology usage for teaching and learning law in open and distance learning: a Sri Lankan perspective. https://www.emerald.com/insight/2414-6994.htm (Accessed 13 April 2020).

Severiens, S., Wolff, R., \& Van Herpen, S. (2014). Teaching for diversity: a literature overview and an analysis of the curriculum of a teacher training college. European Journal of Teacher Education, 37(3), 295-311. https://doi.org/10.1080/02619768.2013.845166.

Sharma, R. C. Kawachi, P. \& Bozkurt, A. (2019). Exploring Changing Perspectives in Distance Education. Asian Journal of Distance Education, 14 (1), 1 - 6.

Shin, N. (2003). Transactional Presence as a Critical Predictor of Success in Distance Learning. Distance Education, 24, 69-86.

Siemens, G. (2005). A learning theory for the digital age. Instructional Technology and Distance Education, 2(1), 3-10.

Singh, L. \& Das, M. (2019). Using Innovative Measures for Enhancing Quality in the ODL System in India. Asian Journal of Distance Education, 14 (1), 117 - 127

Schophuizen, M. (2020). What is Openness in Open Education? https://frankounl.wordpress.com/2014/12/24/ (Accessed 26 April 2020).

Srivastava, M., Kurup, J. M., and Nembiakkim, R. (2007). Reaching out to the un-reached through ODL: role of IGNOU in the North East Region. Indian Journal of Open Learning, 16 (2).

Tait, A. (2000). Planning Student Support for Open and Distance Teaching, Open Learning, 15(3), pp.287-299. 
Tomei, L. (2008). Online and distance learning, concepts, methodologies tools, and applications. New York: Information Science.

Trindade, A. R. Carmo, H. Bidarra, J. (2000). Current Developments and Best Practice in Open and Distance Learning. International Review of Research in Open and Distance Learning, 1(1), 1-25.

Turow, I. (2016). Media today: Mass Communication in a Converging World. https://books.google.com/books?id=4CQ1DwAAQBAJ\&pg=PA377\&lpg=PA377\& dq.

UNESCO (2015), http://www.unesco.org/en/efa.

UNESCO (2002). Open and Distance Learning - Trends, Policy and Strategy Considerations, Paris: United Nations Educational, Scientific, and Cultural Organization.

University of South Africa (UNISA) (2008). Open distance learning policy. Pretoria: UNISA. 
Creative Commons licensing terms

Authors will retain the copyright of their published articles agreeing that a Creative Commons Attribution 4.0 International License (CC BY 4.0) terms will be applied to their work. Under the terms of this license, no permission is required from the author(s) or publisher for members of the community to copy, distribute, transmit or adapt the article content, providing a proper, prominent and unambiguous attribution to the authors in a manner that makes clear that the materials are being reused under permission of a Creative Commons License. Views, opinions and conclusions expressed in this research article are views, opinions and conclusions of the author(s). Open Access Publishing Group and European Journal of Open Education andE-learning Studies shall not be responsible or answerable for any loss, damage or liability caused in relation to/arising out of conflict of interests, copyright violations and inappropriate or inaccurate use of any kind content related or integrated on the research work. All the published works are meeting the Open Access Publishing requirements and can be freely accessed, shared, modified, distributed and used in educational, commercial and non-commercial purposes under a Creative Commons Attribution 4.0 International License (CC BY 4.0). 